\title{
Effects of pre-mating nutrition on mRNA levels of developmentally relevant genes in sheep oocytes and granulosa cells
}

\author{
Laura F Pisani, Stefania Antonini, Paola Pocar, Stefania Ferrari, Tiziana A L Brevini, \\ Stewart M Rhind ${ }^{1}$ and Fulvio Gandolfi \\ Laboratory of Biomedical Embryology, Department of Animal Science, University of Milan, Via Celoria 10, \\ 20133 Milano, Italy and ${ }^{1}$ The Macaulay Institute, Craigiebuckler, Aberdeen, AB15 8QH, UK
}

Correspondence should be addressed to F Gandolfi; Email: fulvio.gandolfi@unimi.it

L F Pisani and S Antonini contributed equally to this work

L F Pisani is now at Livestock Genomics 2, CERSA, Parco Tecnologico Padano, 26900 Lodi, Italy

\begin{abstract}
The present study was designed to investigate the relationship between pre-mating nutrition and the relative amounts of a panel of developmentally relevant genes in ovine oocytes and granulosa cells. Cast age ewes were fed a ration providing $0.5 \times(0.5 \mathrm{M})$ or $1.5 \times(1.5 \mathrm{M})$ live weight maintenance requirements for 2 weeks before slaughter. The ewes were synchronized and superovulated with FSH and pregnant mares serum gonadotropin. At slaughter, oocytes and granulosa cells were aspirated from follicles $>2$ mm in diameter and the relative abundance of 8 and 17 transcripts in oocytes and granulosa cells respectively were analyzed by semi-quantitative RT-PCR. In the oocytes, no differences between groups were observed for five transcripts (GDF9, BMP15, c-kit, glucose transporter 1 (SLC2A1), and hexokinase 1), but a lower amount of glucose transporter 3 (SLC2A3), sodium/glucose cotransporter 1 (SLC5A1), and $\mathrm{Na}^{+} / \mathrm{K}^{+}$ATPase mRNAs was detected in the $0.5 \mathrm{M}$ group. Increased expression of PTGS2, HAS2, and the leptin receptor long form was observed in granulosa cells from the $0.5 \mathrm{M}$ group. No differences between groups were observed for the other transcripts (early growth response factor-1, estrogen receptor- $\alpha, \mathrm{LH}$ and FSH receptors, gremlin 1, pentraxin 3, KIT ligand, glucose transporters 1, 3, and 8, IGF1, IGF1 receptor, leptin receptor, and tumor necrosis factor-stimulated gene 6). Expression of leptin and sodium/glucose cotransporter 1 was not detected in both groups. The present data indicate that pre-mating nutrition is associated with alteration in the mRNA content in oocytes and surrounding follicle cells in ewes, which may account for the reduced reproductive performance typical of ewes that are fed a restricted ration for a short period of time before mating.

Reproduction (2008) 136 303-312
\end{abstract}

\section{Introduction}

Nutrition has a significant impact on numerous reproductive functions including hormone production, fertilization, and early embryonic development, both in vivo and in vitro (Boland et al. 2001, Armstrong et al. 2003).

Ovulation and lambing rates in sheep are positively influenced by both the level of pre-mating food intake (Gunn et al. 1979) and the separate, but related, factor, body condition at mating (Gunn \& Doney 1979). While the effects of higher levels of body condition have been shown to be expressed, at least in part, through an increased population of large, potentially ovulatory, ovarian follicles around the time of mating (McNeilly et al. 1987), increased levels of food intake before mating do not result in any difference in numbers of large follicles (Rhind \& McNeilly 1998). Thus, the differences in ovulation rate associated with the level of food intake must be a function of changes in ovarian activity and in the final processes of oocyte maturation.

It has been shown that reduced intake is associated with a reduced incidence of luteinizing hormone (LH) pulses during the days before ovulation (Rhind et al. 1985) and, in recent studies, reduced cleavage rates of oocytes were observed in ewes fed a low energy $(0.5 \times$ energy requirements) diet in comparison with a high energy (1.5× energy requirements) diet (Papadopoulos et al. 2001, Lozano et al. 2003, Borowczyk et al. 2006). Low cleavage rate was also observed in overfed (ad libitum intake) ewes (Lozano et al. 2003, Borowczyk et al. 2006). Furthermore, Borowczyk et al. (2006) observed that the number of blastocysts and the rate of blastocyst formation were lower for underfed ewes compared with control ewes. Taken together, these data indicate that acute changes in sheep nutrition (underfeeding or feeding 
ad libitum) during pre-mating period also result in reduced oocyte quality and embryonic development.

The capacity of an oocyte to develop into a normal embryo is acquired within the ovary during the developmental stages that precede ovulation through a process referred to as 'oocyte capacitation' (Hyttel et al. 1997). Although the precise mechanisms have not been fully elucidated, during capacitation, oocytes become equipped for future embryonic development, storing the information acquired during their growth and maturation for use at the appropriate stage of development (Brevini Gandolfi \& Gandolfi 2001).

During the interval between fertilization and so-called maternal-embryonic transition, when transcriptional activity is switched on, embryo function is supported by maternal RNAs and proteins synthesized during oogenesis. This implies that RNA and protein molecules can be synthesized as much as several weeks before they are used. A number of strategies to optimize their storage in a quiescent form and to allow their use at the appropriate time during oocyte maturation and early embryonic development have evolved. In particular, it has been shown that oocyte quality and, ultimately, its capacity to lead to sustainable embryonic development depends on the efficiency of such storage process (Gandolfi et al. 2005) which, in turn, depends upon an intimate association between the somatic follicular cells and the developing germ cells (Downs \& HunzickerDunn 1995). Furthermore, oocyte-granulosa cell communication is bidirectional and essential for both oocyte and follicular somatic cell function and development (Eppig et al. 1997).

The aim of this study was to determine whether or not nutrition affects the amount of mRNA molecules stored in the ooplasm and the level of gene expression of granulosa cells. To address this, we determined the relative abundance of a panel of genes in oocytes and granulosa cells derived from underfed versus normally fed ewes. The genes analyzed in the oocytes are involved in important aspects of maturation, such as quality (growth differentiation factor 9 (GDF9), bone morphogenetic protein 15 (BMP15), and c-kit) and metabolism (glucose transporters 1 and 3 (SLC2A1 and SLC2A3), sodium/glucose cotransporter 1 (SLC5A1), $\mathrm{Na}^{+} / \mathrm{K}^{+}$ATPase, and hexokinase $\left.1(H K 1)\right)$. The genes selected for the analysis of granulosa cells are related to the endocrine status (estrogen receptor- $\alpha$ (ESR1) and LH and follicle-stimulating hormone (FSH) receptors), cell-specific activity (prostaglandin $\mathrm{G} / \mathrm{H}$ synthase and cyclooxygenase (PTGS2), early growth response factor 1 (EGR1), hyaluronic acid synthase 2 (HAS2), gremlin 1 (GREM1), KIT ligand, pentraxin 3 (PTX3), and tumor necrosis factor-stimulated gene 6 (TNFAIP6)), and metabolism (insulin-like growth factor-1, IGF1 receptor, glucose transporters $1,3,8$ (SLC2A8), SLC5A1, leptin, and leptin receptors).

\section{Results}

\section{Animal live weights and condition scores}

At the time of slaughter, animals of the low intake $(\mathrm{L})$ and high intake $(\mathrm{H})$ groups had mean ( \pm s.E.M.) live weights of $52.8 \pm 1.60$ and $56.9 \pm 3.25 \mathrm{~kg}$ and mean ( \pm s.E.M.) condition scores of $2.32 \pm 0.042$ and $2.50 \pm 0.060$ respectively.

\section{Number of follicles and superovulatory response}

The dietary intake, $1.5 \times$ maintenance $(1.5 \mathrm{M})$ and $0.5 \times$ maintenance $(0.5 \mathrm{M})$, did not influence either the total number of follicles or the number of follicles in each category we considered ( $2-4$ and $>4 \mathrm{~mm}$ ) as summarized in Table 1.

\section{Oocyte mRNA profiles}

Transcripts for all of the eight evaluated genes were detected in oocytes from both 1.5 and $0.5 \mathrm{M}$ animals. The analysis of the three genes related to oocyte quality (e.g. GDF9, BMP15, c-kit) showed no statistically significant differences between groups (Fig. 1).

Among genes related to oocyte metabolism, SLC2A3 and SLC5A1 mRNA levels were found to be lower in ewes fed $0.5 \mathrm{M}$ compared with those fed $1.5 \mathrm{M}$ $(P \leq 0.05)$, but only in the oocytes isolated from follicles with a diameter greater than $4 \mathrm{~mm}$. In addition, a lower amount of the $\mathrm{Na}^{+} / \mathrm{K}^{+}$ATPase transcript was measured in the $0.5 \mathrm{M}$ group, independently of follicle diameter. No differences between groups were found for the other transcripts investigated (SLC2A1, HK1, see Fig. 2).

\section{Granulosa cells mRNA profile}

No differences in gene expression were observed in relation to follicle diameter for any of the genes analyzed and so data are presented independently of follicle size.

Analysis of the expression levels of genes related to follicle endocrine function (ESR1, and FSH and $\mathrm{LH}$ receptors) showed no significant differences between groups (Fig. 3).

Table 1 Effect of dietary intake on number of follicles and their distribution by diameter.

\begin{tabular}{lrr}
\hline Follicle diameter & \multicolumn{2}{c}{ Dietary intake } \\
\cline { 2 - 3 } & \multicolumn{1}{c}{$1.5 \mathrm{M}^{\mathrm{a}}$} & \multicolumn{1}{c}{$0.5 \mathrm{M}^{\mathrm{a}}$} \\
\hline $2-4 \mathrm{~mm}$ & $9.3 \pm 1.3$ & $9.8 \pm 0.9$ \\
$>4 \mathrm{~mm}$ & $9.2 \pm 0.7$ & $8.2 \pm 0.6$ \\
Total follicles $\times$ ovary & $18.5 \pm 1.2$ & $18 \pm 1.5$
\end{tabular}

Data are expressed as mean \pm s.E.M.

${ }^{\mathrm{a}} \mathrm{M}$, maintenance energy requirement. 

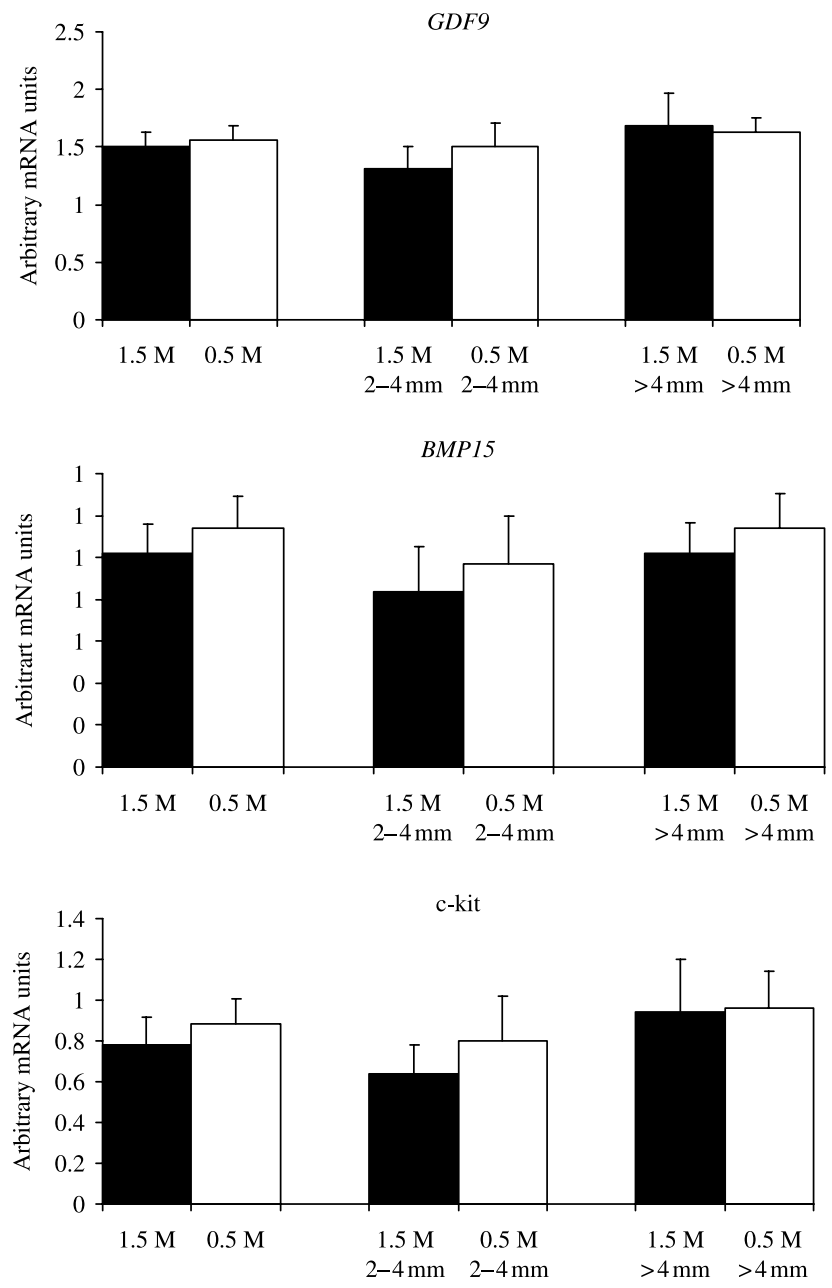

Figure 1 Effect of maternal nutrition on oocyte quality-related gene expression. Values are means \pm s.E.M.

Among genes related to follicle development (HAS2, EGR1, PTGS2, KIT ligand, GREM1, PTX3, and TNFAIP6) expression of PTGS2 in the $1.5 \mathrm{M}$ group was virtually absent, whereas a consistent expression was detected in the $0.5 \mathrm{M}$ group. Furthermore, an up-regulation of HAS2 mRNA was found in ewes fed with $0.5 \mathrm{M}$ group compared with the $1.5 \mathrm{M}$ one. No differences were observed for any of the other genes analyzed in this group (Fig. 4).

Among genes related to follicle metabolism, an up-regulation of transcript for the leptin receptor long form was observed in the $0.5 \mathrm{M}$ group compared with the $1.5 \mathrm{M}$. No significant differences were observed for the other transcripts analyzed (SLC2A1,SLC2A3, $S L C 2 A 8$, IGF1, IGF1 receptor, and leptin receptor; Fig. 5). Transcripts for SLC5A1 and leptin were not found in granulosa cells from the two groups.

\section{Immunoblotting analysis of granulosa cells}

PTGS2 protein in granulosa cells was detected as a single strong band of the expected molecular weight only
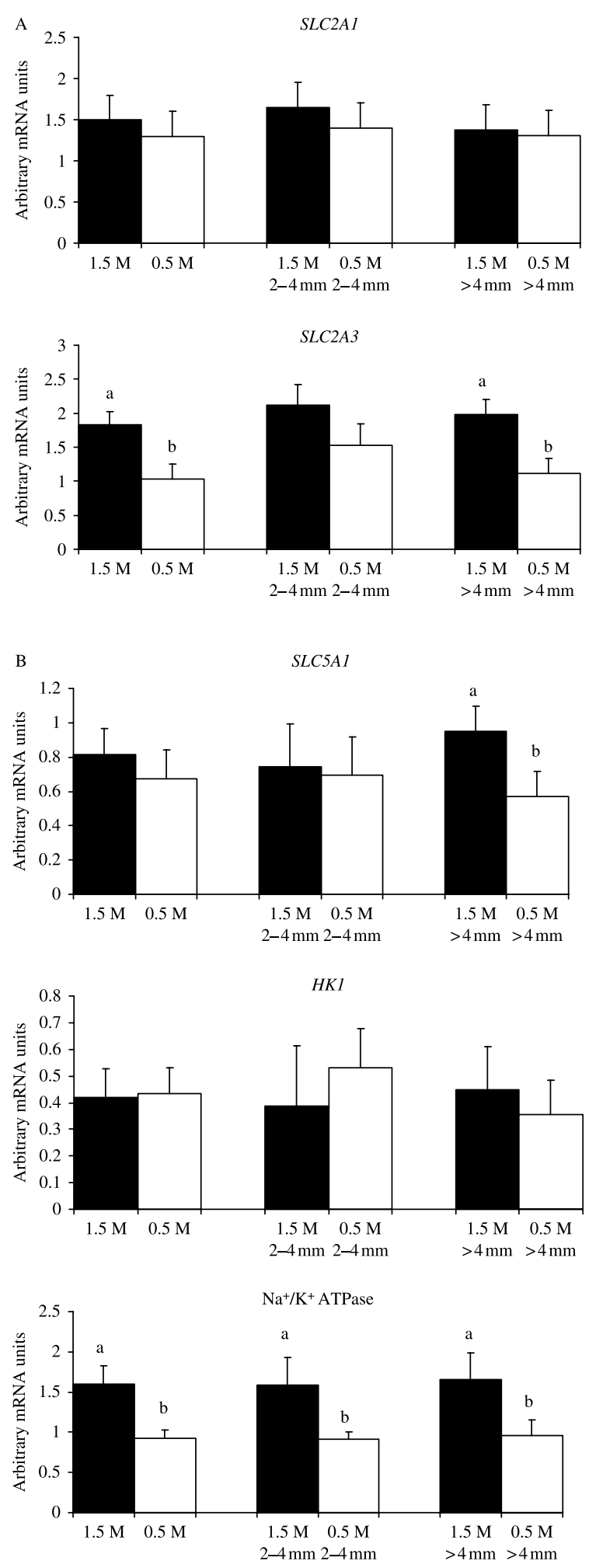

Figure 2 ( $A$ and $B$ ) Effect of maternal nutrition on oocyte metabolismrelated gene expression. Values are means \pm s.E.M. Different letters within columns indicate statistical difference $(P<0.05)$. 


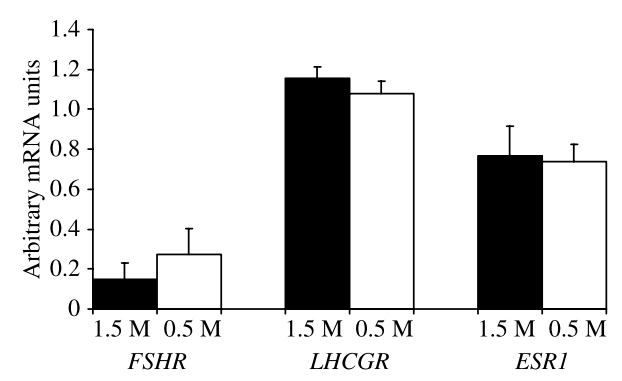

Figure 3 Effect of maternal nutrition on granulosa cells endocrinerelated genes expression. Values are means \pm S.E.M.

among the constitutive proteins of cells isolated from ewes fed $0.5 \mathrm{M}$, whereas no specific signal was visible in the $1.5 \mathrm{M}$ group (Fig. 6). This reflected exactly the data obtained analyzing PTGS2 transcript. Unfortunately, it was not possible to perform a similar analysis on the other genes that showed differences between the experimental groups either because suitable antibodies were not commercially available, as in the case of granulosa cells, or not enough proteins were available, as in the case of oocytes.

\section{Discussion}

Pre-mating levels of food intake can influence the ovulation rate in sheep without changing the numbers of large, potentially ovulatory follicles present in the ovary (Rhind \& McNeilly 1998). However, the underlying differences in gene expression and physiology that result in differential rates of follicle maturation and ovulation during the $48 \mathrm{~h}$ before ovulation have not been
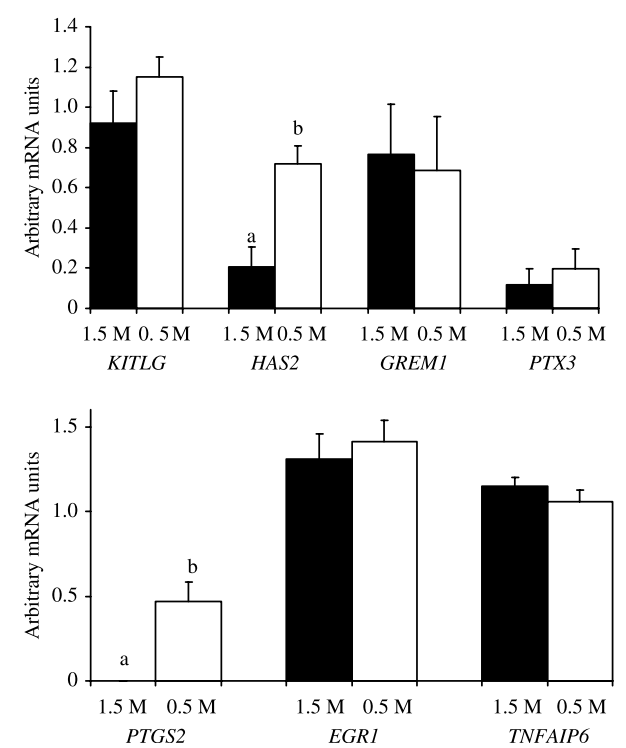

Figure 4 Effect of maternal nutrition on granulosa cells quality-related genes expression. Different letters within columns indicate statistical difference $(P<0.05)$.
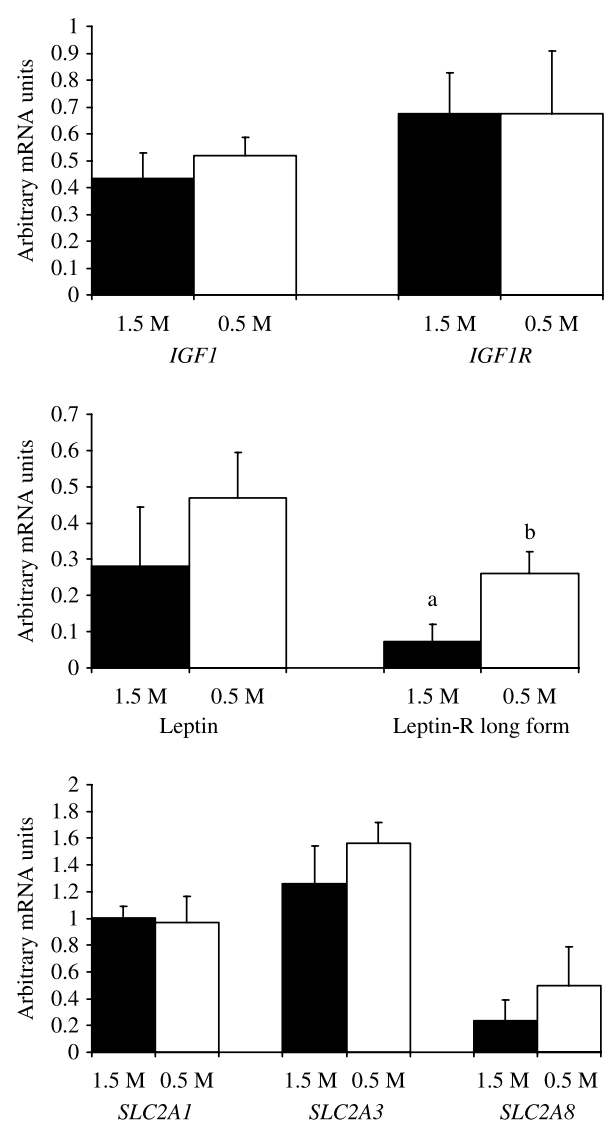

Figure 5 Effect of maternal nutrition on granulosa cells metabolismrelated genes expression. Different letters within columns indicate statistical difference $(P<0.05)$.

elucidated. To our knowledge, this is the first study investigating the association between the pre-mating nutritional status and the expression level of a panel of developmentally and metabolically relevant genes in the
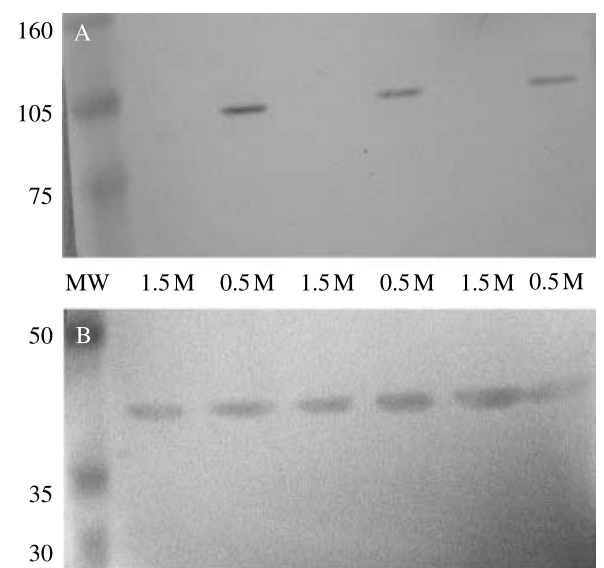

Figure 6 Effect of maternal nutrition on the presence of PTGS2 protein in granulosa cells. (A) Equal amounts of protein were loaded on each lane and probed with an antibody specific for PTGS2. PTGS2 protein is detected only in the $0.5 \mathrm{M}$ group confirming the results obtained analyzing its transcript. (B) Loading control stained with an antibody specific for $\beta$-actin. MW, molecular weight marker. 
oocyte and granulosa cells in ewes. The present data show that an acute reduction of energy intake during the pre-mating period is associated with changes in mRNA levels in both oocyte and surrounding cells.

Analysis of the expression levels of genes related to oocyte quality, such as GDF9 (a gene that promotes the progression of folliculogenesis and oocyte development and maturation), BMP15 (which is involved in oocyte and granulosa cell development), and c-kit (which acts in combination with its ligand to determine the growth of the follicle and the oocyte) showed no differences between groups, independently of follicle diameter. By contrast, differences in pre-mating nutritional planes influenced the expression level of some genes related to the metabolic activity of the oocyte. Specifically, our data indicate a statistical down-regulation of $S L C 2 A 3$, SLC5A1, and $\mathrm{Na}^{+} / \mathrm{K}^{+}$ATPase mRNAs in ewes fed with $0.5 \times$ live weight maintenance requirements.

$\mathrm{SLC} 2 \mathrm{~A} 3$ is one of the passive transporters expressed in pre-implantation embryos and it is involved in glucose uptake (Pantaleon et al. 1997, Augustin et al. 2001). Glucose is the main energy substrate for nuclear maturation in cattle, mice, and pigs (Downs et al. 1998, Downs \& Utecht 1999, Hashimoto et al. 2000, Wongsrikeao et al. 2007) and a deficiency can compromise the ability of the oocyte to reach the second metaphase and to extrude the first polar body (Dominko \& First 1997). The down-regulation of SLC2A3 observed in the present study is in accordance with the reduced level of glucose transporters reported in low quality sheep oocytes (Leoni et al. 2007). In addition, low numbers of glucose transporters have been shown to be associated with low rates of blastocyst production in bovines (Oropeza et al. 2004) and have been postulated to affect embryo compaction and blastulation (Thompson 2000, Block et al. 2007). It is also noteworthy that, in contrast to what has been observed in mice and in humans, where the expression of this glucose transporter begins only at the activation of the embryo genome (Dan-Goor et al. 1997, Pantaleon et al. 1997), in cattle (Augustin et al. 2001) and the present study, $S L C 2 A 3$ is already expressed in immature oocytes. This suggests that SLC2A3 has an important role in early glucose metabolism in these species.

$\mathrm{Na}^{+} / \mathrm{K}^{+}$ATPase is involved in the regulation of cell volume and the transport of glucides and amino acids into cells. Reduced production of $\mathrm{Na}^{+} / \mathrm{K}^{+}$ATPase could impact adversely on oocyte and embryo metabolism. Our study demonstrates that an acute reduction in food intake induces a down-regulation of $\mathrm{Na}^{+} / \mathrm{K}^{+}$ATPase transcript in oocytes; this could account for a reduced level of developmental competence. In fact, this enzyme has been reported to be more abundant in oocytes selected for in vitro maturation compared with discarded ones (De Sousa et al. 1998), and it is also known that antisense oligonucleotide specific for the $\mathrm{Na}^{+} / \mathrm{K}^{+}$ ATPase inhibits blastocysts formation in cattle (Watson et al. 1999). In addition, levels of $\mathrm{Na}^{+} / \mathrm{K}^{+}$ATPase transcript in low competence sheep oocytes are lower than that in high competence ones (Leoni et al. 2007).

The detection, in the $0.5 \mathrm{M}$ group ewes, of lower levels of mRNAs coding for three out of five genes related to oocyte metabolic function suggests that under-nutrition alters oocyte metabolism. It is possible that such changes in transcript levels at this early stage of development could contribute not only to short-term effects on reproductive function but also to long-term reductions in adult reproductive performance (Gunn et al. 1995, Rhind et al. 1998).

In the present study, the expression level of genes related to granulosa cell endocrine functionality ( $\mathrm{FSH}$ and $\mathrm{LH}$ receptors, and estrogen receptor- $\alpha$ ) was not affected by the energy intake levels. This is partially in contrast to the findings of Lozano et al. (2003) who observed that a hypocaloric diet did not affect pituitary FSH levels, but could reduce LH levels. However, this discrepancy could be attributable to the superovulation treatment used in our experiments. Since exogenous gonadotropins cause an increased expression of FSH and LH receptors (LaPolt et al. 1990, 1992), it is possible that superovulation overrode any underlying differences in hormone receptor gene expression induced by the dietary intake. The possibility of effects on oocyte quality of administration of exogenous hormones has been postulated, frequently, but at present it remains conjecture. Although changes in the methylation status of several imprinted genes have been reported in oocytes from stimulated cycles in both the mouse and the human in the latter, the effects of superovulation could not be distinguished from those of donor age and fertility (Sato et al. 2007), indicating that additional, unquantified effects may be involved. While the biological significance of these findings remains unclear, it is possible that the endocrine milieu around the time of conception may affect the outcome of pregnancy (Sinclair 2008). However, within our experimental design, ovarian stimulation was essential in order to obtain enough biological material without incurring the high costs associated with using very large numbers of individual animals. Two genes involved in follicle growth and cumulus expansion, PTGS2 and HAS2, showed a significant increase in transcript levels in the $0.5 \mathrm{M}$ group, relative to the $1.5 \mathrm{M}$ group animals. This suggests that the effect of nutrition on these genes is specific since all the other genes involved in follicular development were not influenced by the diet. Moreover, we could confirm that changes of PTGS2 mRNA levels were reflected in the parallel changes of its protein.

PTGS2 is an inducible enzyme essential for follicle prostaglandin production, which is expressed according to a precise time scale during follicular development. In physiological conditions, PTGS2 is expressed by secondary and pre-antral follicles, but it is absent in primary and antral follicles (Tokuyama et al. 2003). Diet restriction 
causes a reduction in availability of lipids (Ye et al. 2005) for prostaglandins synthesis and so the maintenance of PTGS2 expression in antral follicles isolated from sheep subjected to diet restriction may represent a compensatory mechanism for suboptimal amounts of intracellular lipids. At present, it is unclear how diet regulates PTGS2 expression since the expression levels of EGR1 and TNFAIP6 were unaffected even if both genes can up-regulate PTGS2 expression (Richards 2005, Sayasith et al. 2006). HAS2 is normally expressed in the early follicle stages and expression decreases thereafter, followed by a rapid increase some hours before ovulation (Fulop et al. 1997, Salustri et al. 2004). It regulates the formation of a composite extracellular matrix by the cumulus-oocyte complex (Chen et al. 1990, Camaioni et al. 1993), a process critical to ovulation and cumulus expansion. The higher level of HAS2 transcripts measured in the $0.5 \mathrm{M}$ group suggests an anomaly in extracellular matrix deposition, possibly owing to an alteration in the timing of follicular gene expression, which may impair the dynamics of oocyte maturation and the subsequent ovulation process.

Both the leptin receptor and its long form were detected in the granulosa cells of all follicles but only the latter showed a significant up-regulation in the $0.5 \mathrm{M}$ group. Leptin is a protein hormone synthesized by the adipose tissue and transported to the ovaries where it regulates glucose uptake and induces $\mathrm{LH}$ secretion, thereby linking nutritional state and reproductive function (Bucholtz et al. 1996, Nagatani et al. 1996). In the present study, no leptin expression was observed in any of the groups analyzed, a finding in broad agreement with the study of Munoz-Gutierrez et al. (2005) who described a weak expression of leptin only in a small proportion of antral follicles in the sheep, confirming that leptin is mainly produced by adipose tissue and delivered to the ovary through the blood stream.

The level of leptin expression in the hypothalamus increases in well-fed ewes (Dyer et al. 1997), and a high concentration of circulating leptin causes a reduction in the expression of its receptors (Ohtani et al. 2001). On the other hand, nutritional restrictions reduce the blood levels of leptin, which induces an increase of appetite and stimulates the search of food (Chilliard et al. 2005). Taken together, these data suggest that the increase in receptor expression in the underfed ewes may reflect a decrease in circulating leptin with possible consequences for follicle maturation and ovulation. In fact, the leptin/leptin receptor complex represents the main connection between nutrition and hormonal secretion by the hypothalamus-hypophysis-gonad axis (Elmquist et al. 1998, Sawchenko 1998), since a reduction in leptin secretion causes a reduction in $\mathrm{LH}$ and a consequent delay in estrus cycle (Stanley et al. 2000). Furthermore, the leptin receptor long form is specifically involved in this process, influencing GNRH secretion and the following LH outflow (Barb et al. 2005, Kaminski et al. 2006).

In conclusion, our results show that short-term food restriction alters the levels of a few specific transcripts in both oocyte and granulosa cells. Our data indicate that genes involved in oocyte metabolic activity are affected, specifically, and that this phenomenon is accompanied by the deregulation of the correct dynamic of gene expression in granulosa cells. The present study describes the effect of total dietary intake but the future investigations that address specific dietary components should provide further insight into the underlying mechanisms associated with changes in reproductive performance in ewes.

\section{Materials and Methods}

\section{Animals and treatments}

The study was conducted using 16 cast age ewes of proven fertility. They were allocated randomly to two groups with initial mean ( \pm S.E.M.) live weights of $56.1 \pm 1.89 \mathrm{~kg}$ (low intake, $n=10$ ) and $56.0 \pm 2.80 \mathrm{~kg}$ (high intake, $n=6$ ) and mean body condition scores (Russel et al. 1969) of $2.37 \pm 0.034$ and $2.33 \pm 0.064$ respectively, at the start of the study. During the 2-week period before slaughter, low intake animals were fed pelleted rations (Ewe pellets; Harbro Ltd, Turriff, UK) and chopped straw at rates that provided $0.5 \times$ live weight maintenance requirements $(0.5 \mathrm{M})$ and high intake animals were offered the same feeds in amounts that provided $1.5 \times$ live weight maintenance requirements $(1.5 \mathrm{M})$, a level of intake consistent with normal, pre-mating levels of nutrition.

In order to obtain enough material to perform the study with the available number of animals, it was necessary to superovulate them. The estrous cycles of all ewes were synchronized, to control the time of ovulation, by the insertion of intravaginal pessaries containing $30 \mathrm{mg}$ progestagen (Intervet, Cambridge, UK) for 14 days before slaughter. During the days before slaughter, the following protocol was applied: day 3, Ovagen $(\mathrm{oFSH}$, Synergy Products, Melksham, UK), i.m. $1.05 \mathrm{mg}$ at $0800 \mathrm{~h}+$ $1.05 \mathrm{mg}$ at $2000 \mathrm{~h}$; day 2, Ovagen, $1.05 \mathrm{mg}$ at $0800 \mathrm{~h}+1.05 \mathrm{mg}$ at $2000 \mathrm{~h}$; day 1 , Ovagen, $1.05 \mathrm{mg}$ at $0800 \mathrm{~h}+1.05 \mathrm{mg}$ Ovagen +400 i.u. pregnant mares serum gonadotropin (PMSG; $2 \mathrm{ml}$, Intervet) i.m. at $2000 \mathrm{~h}$; and day 0 remove sponge.

\section{Ovary handling and oocyte and granulosa cell recovery}

Reproductive tracts were collected at slaughter and stored in PBS at $\sim 37^{\circ} \mathrm{C}$ during transport to the laboratory. Ovaries were removed and washed once with $\mathrm{PBS}$. The number and diameter of visible follicles were determined. The follicles were individually punctured and follicular fluid was released in a Petri dish. Cumulus oocyte complexes (COCs) were isolated and divided into two groups split according to follicle diameter (2-4 or $>4 \mathrm{~mm}$ ). Under a stereomicroscope, COCs were recovered from each dish and transferred to a Petri dish containing washing mediums TCM 199. For every COC, oocytes were denuded with $2.9 \%$ citric acid and collected in two pools from each sheep, based on follicle diameter. The 
oocytes were washed in washing medium TCM 199 and stored in RNAlater, RNA Stabilization Reagent (Qiagen SpA) until use. Granulosa cells obtained at oocyte retrieval were collected by centrifugation and stored in RNAlater as above.

\section{RNA isolation}

Oocytes of each follicle category of each sheep were pooled for poly $(\mathrm{A})+$ RNA extraction using the Dynabeads mRNA DIRECT Micro-kit (Invitrogen S.r.l) according to the manufacturer's instructions. Briefly, pools were lysed for $10 \mathrm{~min}$ at room temperature in $200 \mu$ l lysis buffer $(100 \mathrm{mmol}$ Tris- $\mathrm{HCl}(\mathrm{pH} 8.0)$, $500 \mathrm{mmol} \mathrm{LiCl}, 10 \mathrm{mmol}$ EDTA, $1 \%(\mathrm{w} / \mathrm{v})$ SDS, and $5 \mathrm{mmol}$ dithiothreitol). After lysis, $10 \mu \mathrm{l}$ pre-washed Dynabeads oligo $(d T)_{25}$ were pipetted into the tube and binding of poly $(\mathrm{A})^{+}$RNAs to oligo(dT) was allowed for $5 \mathrm{~min}$ at room temperature. The beads were then separated with a magnetic separator, washed twice with $30 \mu \mathrm{l}$ washing buffer $(10 \mathrm{mmol}$ Tris$\mathrm{HCl}(\mathrm{pH} 8.0), 0.15 \mathrm{mmol} \mathrm{LiCl}, 1 \mathrm{mmol}$ EDTA, and $0.1 \%(\mathrm{w} / \mathrm{v})$ SDS) and thrice with $30 \mu$ washing buffer $(10 \mathrm{mmol}$ Tris- $\mathrm{HCl}(\mathrm{pH}$ 8.0), $0.15 \mathrm{mmol} \mathrm{LiCl}$, and $1 \mathrm{mmol}$ EDTA). Poly(A) ${ }^{+}$RNAs were then eluted from the beads by incubation in $11 \mu \mathrm{l}$ DEPC-treated sterile water at $65^{\circ} \mathrm{C}$ for $2 \mathrm{~min}$. Aliquots were immediately used for RT. Prior to RNA isolation, $1 \mu$ l exogenous mRNA of rabbit globin $(6.25 \mathrm{pg} / \mu \mathrm{l})$ RNA was added to each oocyte sample as a standard for semi-quantitative analysis of gene expression.

Total RNA was extracted from granulosa cells using TRIzol (Invitrogen) according to the manufacturer's instructions. RNA was dissolved in $20 \mu \mathrm{l}$ DEPC $-\mathrm{H}_{2} \mathrm{O}$, and the concentration and purity were judged by measuring the absorbance at $260 \mathrm{~nm}$ and calculating the ratio of absorbance at 260-280 nm using a u.v. spectrophotometer (SmartSpec 3000, Bio-Rad Laboratories S.r.l).

\section{RT}

RNA from each oocytes pool and granulosa cells replicate $(1 \mu \mathrm{g}$ total RNA) were reverse transcribed into cDNA in a total volume of $20 \mu \mathrm{l}$ reaction mixture containing $8.5 \mu \mathrm{l}$ sterile water, $1 \mu \mathrm{l}$ of $10 \mathrm{mM}$ dNTP mix, and $1 \mu \mathrm{l}$ oligo(dT) $)_{12-18}$ $(500 \mathrm{ng} / \mu \mathrm{l})$. RNA was denatured at $65{ }^{\circ} \mathrm{C}$ for $5 \mathrm{~min}$, and then $4 \mu \mathrm{l}$ of $5 \times$ first-strand buffer $(250 \mathrm{mM}$ Tris- $\mathrm{HCl}(\mathrm{pH} 8.3)$, $375 \mathrm{mM} \mathrm{KCl}$, and $15 \mathrm{mM} \mathrm{MgCl}_{2}$ ), $1.5 \mu \mathrm{l}$ of $50 \mathrm{mM} \mathrm{MgCl}_{2}, 2 \mu \mathrm{l}$ of $0.1 \mathrm{M}$ dithiothreitol, and $1 \mu \mathrm{l}$ of RNaseOUT recombinant RNase inhibitor (Invitrogen, S.r.l, $40 \mathrm{U} / \mu \mathrm{l}$ ) were added. RT was performed with $200 \mathrm{U}$ Superscript II reverse transcriptase (Invitrogen, S.r.l) for $1 \mathrm{~h}$ at $42{ }^{\circ} \mathrm{C}$. Enzymes were inactivated at $70{ }^{\circ} \mathrm{C}$ for $15 \mathrm{~min}$.

\section{Semi-quantitative PCR}

An aliquot of each RT product was subjected to gene-specific PCR (PCR, Table 2) in an automated thermal cycler (iCycler, Bio-Rad Laboratories S.r.l). PCR was performed with CDNA equivalents corresponding to 0.25 oocyte or $100 \mathrm{ng}$ total RNA for granulosa cells. The reaction mix consisted of $0.8 \mu \mathrm{l}$ of $50 \mathrm{mM} \mathrm{MgCl} 2,0.3 \mu \mathrm{l}$ Taq DNA polymerase $(5 \mathrm{U} / \mu \mathrm{l}), 2 \mu \mathrm{l}$ of $10 \times$ PCR buffer (200 mM Tris- $\mathrm{HCl}(\mathrm{pH} \mathrm{8.4),500} \mathrm{mM} \mathrm{KCl),}$

Table 2 Primer pairs used for PCR amplifications of cDNA.

\begin{tabular}{|c|c|c|c|c|c|c|}
\hline Gene & Forward $5^{\prime}-3^{\prime}$ & Reverse $5^{\prime}-3^{\prime}$ & $\begin{array}{c}\text { Annealing } \\
\text { temperature } \\
\left({ }^{\circ} \mathrm{C}\right)\end{array}$ & $\begin{array}{c}\text { PCR } \\
\text { cycles } \\
\text { no. }\end{array}$ & $\begin{array}{l}\text { Product } \\
\text { length } \\
\text { (bp) }\end{array}$ & $\begin{array}{c}\text { GenBank } \\
\text { accession no. }\end{array}$ \\
\hline Globin & GCAGCCACGGTGGCGAGTAT & GTGGGCAGGAGCTTGAAAT & 60 & 35 & 259 & V00875 \\
\hline$\beta$-actin & CCAAGGCCAACCGTGAGAAG & ССАТСТССТGСТTCGAAGTCC & 57 & 26 & 350 & U39357 \\
\hline BMP15 & TCTATTGСССАССТGССТGАG & TGAAGCTGATGGCGGTAAACC & 59 & 30 & 322 & AY885263 \\
\hline GDF9 & TAGTCAGCTGAAGTGGGACA & AGCCATCAGGCTCGATGGCC & 55 & 30 & 400 & DQ304681 \\
\hline c-kit & AGGCATATCCCAAACСТGAACACC & CAACAGGAACAGAACACСТСТGСТ & 60 & 32 & 351 & D45168 \\
\hline$S L C 2 A 1$ & TCGTCGTCGGCATCCTCATC & TCCACCACAAACAGCGAAACG & 60 & 32 & 496 & U89029 \\
\hline$S L C 2 A 3$ & AGGAGGAGGAGAAGGCAAAGG & AAGGCCACAAAGACCAGGTG & 58 & 33 & 478 & NM001009770 \\
\hline$S L C 2 A 8$ & ATGGCTGCCATGCAGTTC & TTTGGTCTCAGGGACACAG & 56 & 34 & 702 & AF495799 \\
\hline SLC5A1 & TCGCAGGACGGTTGTTCATG & СGСТССТСTTTGСTGTTACGC & 58 & 33 & 439 & X82411 \\
\hline $\mathrm{Na}^{+} / \mathrm{K}^{+}$ATPase & ACCTGTTGGGCATCCGAGAGA & AGGGGAAGGCACAGAACCACCA & 60 & 35 & 335 & NM012504 \\
\hline$H K 1$ & TGCGGCTCTCTGATGAAACT & TCCAGGGCGATGAAATCTCC & 57 & 31 & 166 & AF542053 \\
\hline KIT ligand & CGTGTGACTGATGATGTGAAAG & GСTACTGСТGTCATTCСTAAGG & 53 & 34 & 507 & Z50743 \\
\hline PTGS2 & AGGTGTATGTATGAGTGTAGGA & GTGCTGGGCAAAGAATGCAA & 54 & 32 & 483 & U68486 \\
\hline HAS2 & TTTACAATACTCCTGGGTGGTG & ACAATGCCGTACAGTCCCTAG & 54 & 32 & 274 & DY517053 \\
\hline GREM1 & AAGGCCCAGCACAATGACTC & AACGACACTGCTTCACACGC & 59 & 33 & 421 & AY942576 \\
\hline PTX3 & GAGAACTCCGAGTGGACAAGC & CTGCACAGATGGGTCCATGTTC & 58 & 32 & 442 & EE829599 \\
\hline IGF1 & ССТCGСАTСТСТTСТАTСTGGC & САСТСССТСТGСТTGTGTTСTTС & 56 & 30 & 351 & NM001009774 \\
\hline IGF1R & AGCGССТСТАAСТTTGTCTTTG & СССАТТСССАGАGAGAGAGG & 56 & 30 & 297 & AY162434 \\
\hline Leptin & GAACTGTTCCTGGGCACAAG & TTTCAAGGTCCGGAGTTGTC & 55 & 36 & 215 & AF102856 \\
\hline Leptin R & AGGTGAGGTGCAAGAGATTGGA & CGGGGTTTGGTTGCATTCAAG & 55 & 33 & 286 & NM001009763 \\
\hline $\begin{array}{l}\text { Leptin R long } \\
\text { form }\end{array}$ & TCCAAACCСCAAGAACTGTTCC & ТССТGСТСТСАТССТСАСАGGTTA & 55 & 35 & 315 & AB199589 \\
\hline FSHR & AATGTCCTGGCCTTTGTGGTC & GGTCTGGGCTTGCACTTCATAG & 57 & 30 & 348 & L07302 \\
\hline LHCGR & GGGAATGGGTGTAGTGTTGCTG & GCAGCTGAGATGGCAAAGAAAG & 57 & 32 & 473 & L36329 \\
\hline ESR1 & CCATGGAGCATCCAGGGAAG & AGAGGCACCACGTTCTTGCAC & 60 & 28 & 423 & AY033393 \\
\hline EGR1 & CCGACTATCTGTTTCCACAAC & TGAGCTCATCTGAGCGAGAG & 58.5 & 30 & 309 & AY924307 \\
\hline TNFAIP6 & TACAAGCAGCTAGAGGCAGCC & СTTCAAGGTCATGACATTTCСТG & 58 & 26 & 483 & AY919871 \\
\hline
\end{tabular}


$1 \mu \mathrm{l}$ of $10 \mathrm{mM}$ dNTPs, $1 \mu \mathrm{l}$ ( $25 \mathrm{pmol})$ of each sequence-specific primer, and sterile water up to $20 \mu \mathrm{l}$.

For each set of primers, the optimal cycle number at which the transcript was amplified exponentially was established running a linear cycle series, and the number of PCR cycles was kept within this range (Table 2).

An aliquot of each cDNA sample was amplified by PCR with rabbit globin and $\beta$-actin gene-specific primers, for oocytes and granulosa cells respectively.

RT-PCR products were subjected to electrophoresis on a $2 \%$ agarose gel in $1 \times$ TAE buffer $(40 \mathrm{mM}$ Tris-acetate and $1 \mathrm{mM}$ EDTA) containing $0.5 \mu \mathrm{g} / \mathrm{ml}$ ethidium bromide. After electrophoresis at $80 \mathrm{~V}$ for $45 \mathrm{~min}$, the fragments were visualized on a $312 \mathrm{~nm}$ u.v. transilluminator. The image of each gel was recorded using a Kodak digital camera (DC290, SigmaAldrich). The intensity of each band was assessed by densitometric analysis performed with the Labimage software (Kapelan $\mathrm{GmbH}$, Halle, Germany).

The quantification procedure based on direct digitalization of the PCR product after separation on agarose gel provides a wellestablished and sensitive method to detect even small differences in amounts of mRNA from different biological samples (Grover et al. 2001, Ringhoffer et al. 2001). The relative amount of the mRNA of interest was calculated by dividing the intensity of the band for each gene of interest by the intensity of the globin and $\beta$-actin band for oocyte and granulosa cells respectively, as described previously (Wrenzycki et al. 2002, Brevini et al. 2004).

To account for gel to gel variations, each band was normalized against the $350 \mathrm{bp}$ band of a $50 \mathrm{bp}$ ladder marker (Invitrogen cat n. 10416-014, Stenman et al. 1999).

\section{Protein extraction, gel electrophoresis, Western blotting, and immunostaining}

Cells were homogenized, lysed, and constitutive proteins were extracted. Protein concentration was assessed by the Coomassie Blu-G Dye-binding methods (Read \& Northcote 1981). Aliquots of $100 \mu \mathrm{g}$ were prepared and resuspended in sample buffer consisting of $10 \%(\mathrm{w} / \mathrm{v})$ glycerol, $2.3 \%(\mathrm{w} / \mathrm{v})$ SDS, and $6.25 \mathrm{M}$ Tris- $\mathrm{HCl}(\mathrm{pH}$ 6.8) and electrophoresed on a $10 \%$ SDSpolyacrylamide slab gel (Laemmli 1970). Proteins were then transferred onto nitrocellulose filters according to (Towbin et al. 1979), using $0.5 \mathrm{~A} / \mathrm{cm}^{2}$. Equal sample loading and transfer efficiency were confirmed by staining of the membrane with Ponceau Red. The membrane was probed with a specific rabbit polyclonal antibody (diluted in the ratio of 1:500) raised against PTGS2 (ab15839; Abcam, Cambridge, UK) and with a MAB specific for $\beta$-actin (Sigma, A5441) as a loading control. The specific IgG biotin conjugates (Calbiochem, San Diego, CA, USA) were used as secondary antibodies, and the presence of immunoreactivity for the molecules of interest was visualized using Auroprobe BL plus streptavidin/Silver enhancement Reagent IntenSE BL (Amersham, GE Health Care).

\section{Statistical analysis}

Statistical analysis was performed using the unpaired $t$-test or the Mann-Whitney rank sum test, as appropriate, using the Sigma Stat statistical package (Systat Software Inc., San Jose,
CA, USA). Data are presented as mean percentages ( \pm s.E.M.) of a minimum of three independent animals. In all cases, differences of $P \leq 0.05$ were considered significant.

\section{Declaration of interest}

The authors declare that there is no conflict of interest that would prejudice the impartiality of this scientific work.

\section{Funding}

This work was supported by the University of Milan FIRST 2006 and the Scottish Executive Environment and Rural Affairs Department.

\section{Acknowledgements}

The authors are grateful to Valentina Tosetti for her help with the collection of the experimental material.

\section{References}

Armstrong DG, Gong JG \& Webb R 2003 Interactions between nutrition and ovarian activity in cattle: physiological, cellular and molecular mechanisms. Reproduction Supplement 61 403-414.

Augustin R, Pocar P, Navarrete-Santos A, Wrenzycki C, Gandolfi F, Niemann H \& Fischer B 2001 Glucose transporter expression is developmentally regulated in in vitro derived bovine preimplantation embryos. Molecular Reproduction and Development 60 370-376.

Barb CR, Hausman GJ \& Czaja K 2005 Leptin: a metabolic signal affecting central regulation of reproduction in the pig. Domestic Animal Endocrinology 29 186-192.

Block J, Fischer-Brown AE, Rodina TM, Ealy AD \& Hansen PJ 2007 The effect of in vitro treatment of bovine embryos with IGF1 on subsequent development in utero to day 14 of gestation. Theriogenology 68 153-161.

Boland MP, Lonergan P \& O'Callaghan D 2001 Effect of nutrition on endocrine parameters, ovarian physiology, and oocyte and embryo development. Theriogenology 55 1323-1340.

Borowczyk E, Caton JS, Redmer DA, Bilski JJ, Weigl RM, Vonnahme KA, Borowicz PP, Kirsch JD, Kraft KC, Reynolds LP et al. 2006 Effects of plane of nutrition on in vitro fertilization and early embryonic development in sheep. Theriogenology 84 1593-1599.

Brevini TA, Cillo F, Colleoni S, Lazzari G, Galli C \& Gandolfi F 2004 Expression pattern of the maternal factor zygote arrest 1 (Zar1) in bovine tissues, oocytes, and embryos. Molecular Reproduction and Development 69 375-380.

Brevini Gandolfi TAL \& Gandolfi F 2001 The maternal legacy to the embryo: cytoplasmic components and their effects on early development. Theriogenology 55 1255-1276.

Bucholtz DC, Vidwans NM, Herbosa CG, Schillo KK \& Foster DL 1996 Metabolic interfaces between growth and reproduction. V. Pulsatile luteinizing hormone secretion is dependent on glucose availability. Endocrinology 137 601-607.

Camaioni A, Hascall VC, Yanagishita M \& Salustri A 1993 Effects of exogenous hyaluronic acid and serum on matrix organization and stability in the mouse cumulus cell-oocyte complex. Journal of Biological Chemistry 268 20473-20481.

Chen L, Wert SE, Hendrix EM, Russell PT, Cannon M \& Larsen WJ 1990 Hyaluronic acid synthesis and gap junction endocytosis are necessary for normal expansion of the cumulus mass. Molecular Reproduction and Development 26 236-247.

Chilliard Y, Delavaud C \& Bonnet M 2005 Leptin expression in ruminants: nutritional and physiological regulations in relation with energy metabolism. Domestic Animal Endocrinology 29 3-22. 
Dan-Goor M, Sasson S, Davarashvili A \& Almagor M 1997 Expression of glucose transporter and glucose uptake in human oocytes and preimplantation embryos. Human Reproduction 12 2508-2510.

Dominko T \& First NL 1997 Timing of meiotic progression in bovine oocytes and its effect on early embryo development. Molecular Reproduction and Development 47 456-467.

Downs SM \& Hunzicker-Dunn M 1995 Differential regulation of oocyte maturation and cumulus expansion in the mouse oocyte-cumulus cell complex by site-selective analogs of cyclic adenosine monophosphate. Developmental Biology 172 72-85.

Downs SM \& Utecht AM 1999 Metabolism of radiolabeled glucose by mouse oocytes and oocyte-cumulus cell complexes. Biology of Reproduction 60 1446-1452.

Downs SM, Humpherson PG \& Leese HJ 1998 Meiotic induction in cumulus cell-enclosed mouse oocytes: involvement of the pentose phosphate pathway. Biology of Reproduction 58 1084-1094.

Dyer CJ, Simmons JM, Matteri RL \& Keisler DH 1997 Leptin receptor mRNA is expressed in ewe anterior pituitary and adipose tissues and is differentially expressed in hypothalamic regions of well-fed and feedrestricted ewes. Domestic Animal Endocrinology 14 119-128.

Elmquist JK, Bjorbaek C, Ahima RS, Flier JS \& Saper CB 1998 Distributions of leptin receptor mRNA isoforms in the rat brain. Journal of Comparative Neurology 395 535-547.

Eppig JJ, Chesnel F, Hirao Y, O'Brien MJ, Pendola FL, Watanabe S \& Wigglesworth K 1997 Oocyte control of granulosa cell development: how and why. Human Reproduction 12 127-132.

Fulop C, Salustri A \& Hascall VC 1997 Coding sequence of a hyaluronan synthase homologue expressed during expansion of the mouse cumulus-oocyte complex. Archives of Biochemistry and Biophysics 337 261-266.

Gandolfi F, Brevini TA, Cillo F \& Antonini S 2005 Cellular and molecular mechanisms regulating oocyte quality and the relevance for farm animal reproductive efficiency. Revue Scientifique et Technique 24 413-423.

Grover PK, Stapleton AM, Miyazawa K \& Ryall RL 2001 Simple, sensitive and accurate method for the quantification of prothrombin mRNA by using competitive PCR. Biochemical Journal 356 111-120.

Gunn RG \& Doney JM 1979 Fertility in cheviot ewes. 1. The effect of body condition at mating on ovulation rate and early embryo mortality in North Country and South Country Cheviot ewes. Animal Production 29 11-16.

Gunn RG, Doney JM \& Smith WF 1979 Fertility in cheviot ewes. 2. The effect of level of premating nutrition on ovulation rate and early embryo mortality in North Country and South Country Cheviot ewes in moderately-good condition at mating. Animal Production 29 17-23.

Gunn RG, Sim D \& Hunter EA 1995 Effects of nutrition in utero and in early life on the subsequent lifetime reproductive performance of Scottish Blackface ewes in two management systems. Animal Science 60 223-230.

Hashimoto S, Minami N, Yamada M \& Imai H 2000 Excessive concentration of glucose during in vitro maturation impairs the developmental competence of bovine oocytes after in vitro fertilization: relevance to intracellular reactive oxygen species and glutathione contents. Molecular Reproduction and Development 56 520-526.

Hyttel P, Fair T, Callesen H \& Greve T 1997 Oocyte growth, capacitation and final maturation in cattle. Theriogenology 47 23-32.

Kaminski T, Smolinska N, Gajewska A, Siawrys G, Okrasa S, Kochman K \& Przala J 2006 Leptin and long form of leptin receptor genes expression in the hypothalamus and pituitary during the luteal phase and early pregnancy in pigs. Journal of Physiology and Pharmacology 57 95-108.

Laemmli UK 1970 Cleavage of structural proteins during the assembly of the head of bacteriophage $\mathrm{T}_{4}$. Nature 227 680-685.

LaPolt PS, Oikawa M, Jia XC, Dargan C \& Hsueh AJ 1990 Gonadotropininduced up- and down-regulation of rat ovarian LH receptor message levels during follicular growth, ovulation and luteinization. Endocrinology 126 3277-3279.

LaPolt PS, Tilly JL, Aihara T, Nishimori K \& Hsueh AJ 1992 Gonadotropininduced up- and down-regulation of ovarian follicle-stimulating hormone (FSH) receptor gene expression in immature rats: effects of pregnant mare's serum gonadotropin, human chorionic gonadotropin, and recombinant FSH. Endocrinology 130 1289-1295.
Leoni GG, Bebbere D, Succu S, Berlinguer F, Mossa F, Galioto M, Bogliolo L, Ledda S \& Naitana S 2007 Relations between relative mRNA abundance and developmental competence of ovine oocytes. Molecular Reproduction and Development 74 249-257.

Lozano JM, Lonergan P, Boland MP \& O'Callaghan D 2003 Influence of nutrition on the effectiveness of superovulation programmes in ewes: effect on oocyte quality and post-fertilization development. Reproduction 125 543-553.

McNeilly AS, Jonassen JA \& Rhind SM 1987 Reduced ovarian follicular development as a consequence of poor body condition in ewes. Acta Endocrinologica 115 75-83.

Munoz-Gutierrez M, Findlay PA, Adam CL, Wax G, Campbell BK, Kendall NR, Khalid M, Forsberg M \& Scaramuzzi RJ 2005 The ovarian expression of mRNAs for aromatase, IGF-I receptor, IGF-binding protein$2,-4$ and -5 , leptin and leptin receptor in cycling ewes after three days of leptin infusion. Reproduction 130 869-881.

Nagatani S, Bucholtz DC, Murahashi K, Estacio MA, Tsukamura H, Foster DL \& Maeda KI 1996 Reduction of glucose availability suppresses pulsatile luteinizing hormone release in female and male rats. Endocrinology 137 1166-1170.

Ohtani K, Sakamoto H, Kikuchi A, Nakayama Y, Idei T, Igarashi N, Matukawa T \& Satoh K 2001 Follicle-stimulating hormone promotes the growth of human epithelial ovarian cancer cells through the protein kinase C-mediated system. Cancer Letters 166 207-213.

Oropeza A, Wrenzycki C, Herrmann D, Hadeler KG \& Niemann H 2004 Improvement of the developmental capacity of oocytes from prepubertal cattle by intraovarian insulin-like growth factor-I application. Biology of Reproduction 70 1634-1643.

Pantaleon M, Harvey MB, Pascoe WS, James DE \& Kaye PL 1997 Glucose transporter GLUT3: ontogeny, targeting, and role in the mouse blastocyst. PNAS 94 3795-3800.

Papadopoulos S, Lonergan P, Gath V, Quinn KM, Evans AC, O'Callaghan D \& Bolan MP 2001 Effect of diet quantity and urea supplementation on oocyte and embryo quality in sheep. Theriogenology 55 1059-1069.

Read SM \& Northcote DH 1981 Minimization of variation in the response to different proteins of the Coomassie blue G dye-binding assay for protein. Analytical Biochemistry 116 53-64.

Rhind SM \& McNeilly AS 1998 Effects of level of food intake on ovarian follicle number, size and steroidogenic capacity in the ewe. Animal Reproduction Science $\mathbf{5 2}$ 131-138.

Rhind SM, Leslie ID, Gunn RG \& Doney JM 1985 Plasma FSH, LH, prolactin and progesterone profiles of Cheviot ewes with different levels of intake before and after mating and associated effects on reproductive performance. Animal Reproduction Science 8 301-313.

Rhind SM, Elston DA, Jones JR, Rees JR, McMillen SR \& Gunn RG 1998 Effects of restriction of growth and development of Brecon Cheviot ewelambs on subsequent lifetime reproductive performance. Small Ruminant Research 30 121-126.

Richards JS 2005 Ovulation: new factors that prepare the oocyte for fertilization. Molecular and Cellular Endocrinology 23475.

Ringhoffer M, Schmitt M, Karbach J, Jager E, Oesch F \& Arand M 2001 Quantitative assessment of the expression of melanoma-associated antigens by non-competitive reverse transcription polymerase chain reaction. International Journal of Oncology 19 983-989.

Russel AJF, Doney JM \& Gunn RG 1969 Subjective assessment of body fat in live sheep. Journal of Agricultural Science 72 451-454.

Salustri A, Garlanda C, Hirsch E, De Acetis M, Maccagno A, Bottazzi B, Doni A, Bastone A, Mantovani G, Beck Peccoz P et al. 2004 PTX3 plays a key role in the organization of the cumulus oophorus extracellular matrix and in in vivo fertilization. Development 131 1577-1586

Sato A, Otsu E, Negishi H, Utsunomiya T \& Arima T 2007 Aberrant DNA methylation of imprinted loci in superovulated oocytes. Human Reproduction 22 26-35.

Sawchenko PE 1998 Toward a new neurobiology of energy balance, appetite, and obesity: the anatomists weigh in. Journal of Comparative Neurology 402 435-441.

Sayasith K, Brown KA, Lussier JG, Dore M \& Sirois J 2006 Characterization of bovine early growth response factor- 1 and its gonadotropin-dependent regulation in ovarian follicles prior to ovulation. Journal of Molecular Endocrinology 37 239-250. 
Sinclair KD 2008 Assisted reproductive technologies and pregnancy outcomes: mechanistic insights from animal studies. Seminars in Reproductive Medicine 26 153-161.

De Sousa PA, Westhusin ME \& Watson AJ 1998 Analysis of variation in relative mRNA abundance for specific gene transcripts in single bovine oocytes and early embryos. Molecular Reproduction and Development 49 119-130.

Stanley SA, Todd JF, Small CJ, Kim MS, Heath MM, Anand P, Ghatei MA \& Bloom SR 2000 The effects of ciliary neurotrophic factor on the hypothalamo-pituitary gonadal axis in vitro in female rats. Journal of Neuroendocrinology 12 1009-1013.

Stenman J, Finne P, Stahls A, Grenman R, Stenman UH, Palotie A \& Orpana A 1999 Accurate determination of relative messenger RNA levels by RT-PCR. Nature Biotechnology 17 720-722.

Thompson JG 2000 In vitro culture and embryo metabolism of cattle and sheep embryos - a decade of achievement. Animal Reproduction Science 60-61 263-275.

Tokuyama O, Nakamura Y, Musoh A, Honda K, Ozaki K \& Ishiko O 2003 Expression and distribution of cyclooxygenase-2 in human ovary during follicular development. Osaka City Medical Journal 49 39-47.

Towbin H, Staehelin T \& Gordon J 1979 Electrophoretic transfer of proteins from polyacrylamide gels to nitrocellulose sheets: procedure and some applications. PNAS $7 \mathbf{6} 4350-4354$.
Watson AJ, Westhusin ME, De Sousa PA, Betts DH \& Barcroft LC 1999 Gene expression regulating blastocyst formation. Theriogenology 51 117-133.

Wongsrikeao P, Nagai T, Agung B, Taniguchi M, Kunishi M, Suto S \& Otoi T 2007 Improvement of transgenic cloning efficiencies by culturing recipient oocytes and donor cells with antioxidant vitamins in cattle. Molecular Reproduction and Development 74 694-702.

Wrenzycki C, Lucas-Hahn A, Herrmann D, Lemme E, Korsawe K \& Niemann H 2002 In vitro production and nuclear transfer affect dosage compensation of the X-linked gene transcripts G6PD, PGK, and Xist in preimplantation bovine embryos. Biology of Reproduction 66 127-134.

Ye X, Hama K, Contos JJ, Anliker B, Inoue A, Skinner MK, Suzuki H, Amano T, Kennedy G, Arai H et al. 2005 LPA3-mediated lysophosphatidic acid signalling in embryo implantation and spacing. Nature 435 104-108.

Received 31 August 2007

First decision 10 October 2007

Revised manuscript received 16 May 2008

Accepted 28 May 2008 